\title{
Gender Division of Labor, Burnout, and Intention to Leave Work Among Young Female Nurses in Japan: A Cross-Sectional Study
}

\author{
Sachiko Minamizono ${ }^{1}$, Kyoko Nomura ${ }^{1,2, * \mathbb{C}}$, Yuki Inoue ${ }^{3}$, Haruko Hiraike ${ }^{4}$, Akiko Tsuchiya ${ }^{5}$, \\ Hiroko Okinaga ${ }^{2}$ and Jan Illing ${ }^{6}(\mathbb{C}$ \\ 1 Department of Public Health, Akita University Graduate School of Medicine, 1-1-1Hondo, \\ Akita City 010-8543, Japan; sachikot@med.akita-u.ac.jp \\ 2 Support Center for Women Physicians and Researchers, Teikyo University, 2-11-1Kaga, Itabashi-ku, \\ Tokyo 173-8605, Japan; hiokinaga@gmail.com \\ 3 Funabashi Municipal Medical Center, 1-21-1 Kanasugi, Funabashi City, Chiba 273-8588, Japan; \\ inoueyuki112@gmail.com \\ 4 Department of Obstetrics and Gynaecology, Teikyo University School of Medicine, 2-11-1Kaga, Itabashi-ku, \\ Tokyo 173-8605, Japan; haruko.hiraike@gmail.com \\ 5 Nursing Department, Teikyo University Hospital, 2-11-1Kaga, Itabashi-ku, Tokyo 173-8605, Japan; \\ a-tutiya@med.teikyo-u.ac.jp \\ 6 School of Medical Education, Newcastle University, Newcastle upon Tyne, NE2 4HH, UK; \\ Jan.Illing@newcastle.ac.uk \\ * $\quad$ Correspondence: knomura@med.akita-u.ac.jp; Tel.: +81-18-884-6087
}

Received: 17 May 2019; Accepted: 18 June 2019; Published: 21 June 2019

\begin{abstract}
Women in Japan face difficulties balancing work and personal life due to the gender division of labor, and medical professions are no exception. The purpose of this study was to investigate if the gender division of labor affects the intention to leave the workplace among the nursing profession. Among 328 female nurses working for three university-affiliated hospitals in Tokyo, Japan, above 70\% were in their 20s and 30s and single, and agreed with the gender division of labor that men should be the breadwinner and women should assume family responsibilities. Adjusting for three types of Copenhagen burnout inventory, stepwise multivariable logistic regression models identified that being younger (all $p$-values $<0.05$ ), each domain of burnout score (each $p<0.001$ for work-, personal-, and client-related burnout) increased a risk of intention to leave, and high support decreased the risk (all $p<0.001)$. Women who agreed with the gender division of labor were more likely to have intentions to leave $(p=0.003$ but this association disappeared when adjusted. The findings of study demonstrate that perceptions toward gender division of labor are not a determinant of intention to leave the workplace but the young nurses and those who scored high on burnout were the most vulnerable population.
\end{abstract}

Keywords: burnout; gender division of labor; intention to leave; job stress; nurse; support; work-family conflict

\section{Introduction}

The retention of newly certified nurses is important for organizations in terms of cost and time commitment for human resources management [1]. Health care facilities invest thousands of dollars in recruiting and training nurses [2,3]. However, there is an international crisis, as newly graduated nurses are leaving their first place of employment within their first year, having enormous financial 
implications [3-6]. Therefore, it is necessary to improve the working environment for long-term nurse retention resulting in good quality of patient care $[7,8]$.

Nursing is a profession that requires face-to-face contact with patients and their families, and nurses encounter patient suffering and deaths on regular basis. As a result of these negative experiences, newly graduated nurses may experience a reality shock, especially within their first year of employment $[9,10]$. Discrepancies between what they were taught at university and the reality of nursing causes stress and shock for new nurses [11]. Burnout and job dissatisfaction have been found to increase turnover and reduce retention [12]. A preceptorship, known as one-to-one pairing, involves an experienced nurse (nurse preceptor) supervising a less experienced nurse to provide individualized support and teaching [13]. In the setting of teaching hospitals, where the majority of nurses are younger, this places a heavy burden on the preceptor, and particularly on an inexperienced preceptor who is also young $[14,15]$. In this case, young and inexperienced nurses became a high-risk group for psychological burnout as the demands of the job have increased $[6,12]$. In Japan, younger nurses tend to experience high levels of burnout [16]. Such high levels of burnout in younger workers could be due to this group having less professional experience and thus not having sufficient time to formulate effective strategies for dealing with occupational stress $[6,17]$.

According to a governmental survey [18], the most frequent reason given by nurses for leaving their job is "life events" such as pregnancy and childrearing. In Japan, stereotypical gender roles-that men should be the breadwinners and women should assume family responsibility-is prevalent (nearly $40 \%$ ) even among the younger generation in their 20s [19], and is deeply rooted in the mindset of the Japanese population. Previously, we revealed that the idea is also prevalent even among female medical doctors [20]. Consequently, Japanese female medical doctors tend to stop working at the time of childbirth/rearing, which threatens the physician workforce supply in Japan. Short periods of staff retention in the workplace may deprive women of the opportunity for promotion to a leadership position in their profession and may account for the high gender gap index of Japan, which ranks 114 among 144 countries [21].

Previous literature on nurse retention has identified that working conditions, individual characteristics including marital status, and having children influences staff retention [7,22-25]. However, few studies have explored perceptions towards the gender division of labor deeply embedded in mindset of society. Hence, the purpose of this study was to investigate if gender division of labor affects intention to leave the workplace and to identify factors including burnout associated with the intension among the nursing profession in Japan.

\section{Materials and Methods}

\subsection{Participants}

This cross-sectional study used secondary data from a survey of work-family conflict among workers at a large private medical university that has five campuses and three affiliated hospitals. In February 2016, a total of 3493 employees, including 1698 nurses, were invited to participate in the study by mail and 1186, including 441 nurses, provided informed consent and returned the self-administered questionnaires on an anonymous and voluntary basis (overall response rate $34 \%$, response rate for nurses $26 \%$ ). Inclusion criterion was female nurses. Exclusion criteria included faculty members $(n=521)$, other medical personnel $(n=196)$, male staff $(n=34)$, and missing values on every single variable investigated $(n=113)$. This left 328 nurses for analysis. Referring to previous studies that investigated nurse retention, we conceptualized the theoretical framework in Figure 1 [23-25]. For factors for intention to leave at workplace, we collected information about work and personal characteristics, and the perceptions of work-family conflict and gender division of labor. This study was approved by the Teikyo University ethics committee (No.13-1310). 


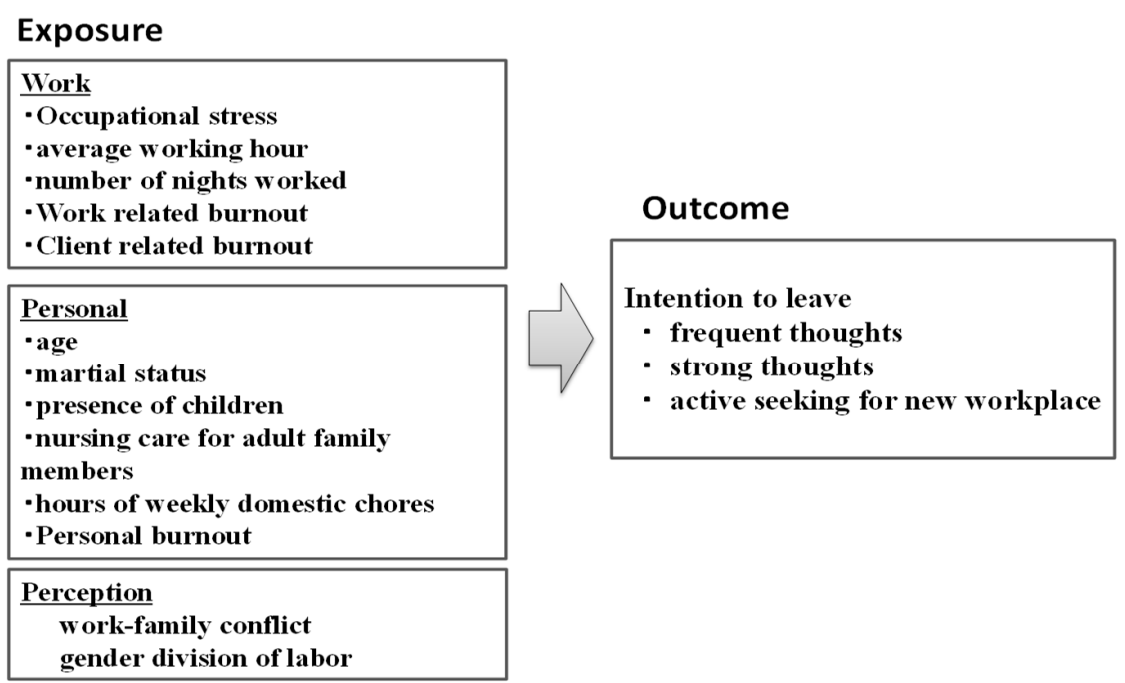

Figure 1. The theoretical framework and hypothesis of this study. Conceptual framework for nurse's intention to leave the workplace.

\subsection{Measures}

The questionnaire items addressed personal factors (age, marital status, caring responsibility of children or adult family members, hours spent doing weekly and weekend domestic chores, personal burnout), work environment characteristics (occupational stress, years in employment, daily working hours, number of nights worked per month, job strain, job support, work related burnout, client related burnout), individual perceptions (perceptions toward gender division of labor and work-family conflict), and intention to leave (frequent thoughts, strong thoughts, and actively seeking new work place). Regarding job strain and job support, we used the Job Contents Questionnaire (JCQ). Burnout was measured by the Copenhagen burnout inventory.

\subsubsection{Intention to Leave}

"Intention to leave" is known as an independent predictor of actual employee retention $[26,27]$ and thus we used this intention as the outcome of interest. Referring to a previous study [28],intention to leave was defined if any of the following three questions received a positive response: (1) frequent thoughts of intention to leave (i.e., I often think of leaving work place); (2) strong thoughts of intention to leave (i.e., I'll leave my work place if I can); and (3) actively seeking a new workplace (i.e., I am actively seeking a new workplace). Responses were based on a Likert scale from strongly disagree (1) to strongly agree (4) and subsequently divided into binary, disagree, or agree.

\subsubsection{Gender Division of Labor}

Gender division of labor was measured based on the following three items that were used for a previous Cabinet Survey [19]: (1) men are expected to fulfill traditional male roles (e.g., breadwinner) and women assume family responsibilities (e.g., household chores); (2) as a woman, being a wife or a mother is more important than work; and (3) for a mother, engagement in childrearing is the first priority. Responses can range from 1 for strongly disagree to 5 for strongly agree. Affirmative perceptions toward gender division of labor are defined when a larger than median summation of these three responses (binary variable) is provided.

\subsubsection{Work-Family Conflict, Burnout, and Occupational Stress}

To measure work-family conflict, we selected the following four questions referring to a previous study [29]: (1) My job occupies lots of my time, which makes it difficult to fulfil family duties; (2) the amount of time required for family responsibilities interferes with my work productivity; (3) I am often 
too exhausted to do anything for my family when I come back from work; and (4) due to psychological burden resulting from my family duties, I often find it difficult to focus on work. Responses were based on a Likert scale from strongly disagree (1) to strongly agree (5). Work-family conflict is defined if summation of (1) and (3), and that of (2) and (4) is higher than the median (binary variable).

We used the Japanese version of the Copenhagen burnout inventory in this study. The Copenhagen burnout inventory examines exhaustion and its attribution to three distinctive aspects: personal, work-related, and client-oriented burnout, and the three scales predict future sickness absence and intention to quit [30]. Personal burnout (PBO) pertains to general symptoms of physical or mental exhaustion, which are not always related to a given particular situation in the work environment and applies to everyone. Work-related burnout (WBO) pertains to symptoms of exhaustion that are related to the work of the subject and applies to everyone in the workforce. Client-related burnout (CBO) pertains to symptoms of exhaustion related to the subject's work with clients and applies to employees in human service work such as nurses and teachers. Thus, "client" can be replaced with "patients" in this study. A total of 19 items were scored on a five-point Linkert scale. The three burnout scores (continuous variable) were calculated by averaging all relevant items, so that higher scores indicate a higher degree of burnout.

Occupational stress has been evaluated by the Job Content Questionnaire (JCQ) based on Karasek's Demand-Control Model [31,32]. The Japanese version of the JCQ is considered to be reliable and valid for assessing job stressors among Japanese employees [33]. This instrument includes scales for job demands, job control, and worksite social support using a Likert Scale format, varying from 1 (strongly disagree) to 4 (strongly agree). Job strain is computed by dividing scores for job demand divided by job control's scale of JCQ and divided into binary variables above and below $75 \%$ (i.e., 0.54 ) of its distribution. Job support was also divided into binary variable with a median (i.e., 24).

\subsection{Data Analysis}

According to age group category, intention to leave was analyzed with all relevant variables using chi-square tests for categorical variables and one-way analysis of variance for contentious variables. A logistic regression model was used to investigate influence of each factor on intention to leave. Odds ratio (OR) was computed along with $95 \%$ confidence intervals (95\% CIs). Multivariable stepwise regression models were used to identify factors associated with intention to leave for each Copenhagen burnout inventory domain. Significance was determined as $5 \%$. All analyses were performed using SAS version 9.4 (SAS Institute Inc., Cary, NC, USA).

\section{Results}

Table 1 indicates age group differences in the items investigated. In total, $76 \%$ were in their $20 \mathrm{~s}$ and 30s (mean, 32 years old) and $69 \%$ were single, about $70 \%$ admitted work-family conflict and $66.7 \%$ of those in their 20s agreed with the gender division of labor. Burnout scores of all three domains and proportions of JCQ support and intention to leave were highest in group of 20-year-olds, although more than half $(56.8 \%)$ of women in their 20 s received high support. 
Table 1. Characteristics according to age group $(N=328)$

\begin{tabular}{|c|c|c|c|c|c|c|c|c|c|}
\hline \multirow{2}{*}{ Variables } & \multicolumn{2}{|c|}{$20-29(N=183)$} & \multicolumn{2}{|c|}{$30-39(N=66)$} & \multicolumn{2}{|c|}{$40-49(N=53)$} & \multicolumn{2}{|c|}{$50-(\mathrm{N}=26)$} & \multirow{2}{*}{$p$} \\
\hline & $N$ & $\%$ & $N$ & $\%$ & $N$ & $\%$ & $N$ & $\%$ & \\
\hline Marital status & & & & & & & & & $<0.001$ \\
\hline Married & 24 & 13.1 & 33 & 50.0 & 32 & 60.4 & 13 & 50.0 & \\
\hline Single (Including Divorced or Widowed) & 159 & 86.9 & 33 & 50.0 & 21 & 39.6 & 13 & 50.0 & \\
\hline Presence of a child & & & & & & & & & $<0.001$ \\
\hline No & 165 & 90.2 & 39 & 59.1 & 22 & 41.5 & 3 & 11.5 & \\
\hline Yes & 18 & 9.8 & 27 & 40.9 & 31 & 58.5 & 23 & 88.5 & $<0.001$ \\
\hline Presence of adult family members who needs nursing care & & & & & & & & & $<0.001$ \\
\hline No & 177 & 96.7 & 63 & 95.5 & 44 & 83.0 & 21 & 80.8 & \\
\hline Yes & 6 & 3.3 & 3 & 4.6 & 9 & 17.0 & 5 & 19.2 & \\
\hline Hours of weekly domestic chores, median $(25 \%, 75 \%)$ & $1(1,3)$ & & $2(1,4)$ & & $4(2,5)$ & & $2(1.5,3)$ & & $<0.001$ \\
\hline Hours of weekend domestic chores, median $(25 \%, 75 \%)$ & $2(1,4)$ & & $4(2,10)$ & & $5(4,11)$ & & $3.75(2,5)$ & & $<0.001$ \\
\hline Work-family conflict & & & & & & & & & 0.610 \\
\hline Low & 50 & 27.3 & 18 & 27.3 & 11 & 20.8 & 9 & 34.6 & \\
\hline High & 133 & 72.7 & 48 & 72.7 & 42 & 79.3 & 17 & 65.4 & \\
\hline Gender division of labor & & & & & & & & & $<0.001$ \\
\hline Disagree & 61 & 33.3 & 30 & 45.5 & 26 & 49.1 & 19 & 73.1 & \\
\hline Agree & 122 & 66.7 & 36 & 54.6 & 27 & 50.9 & 7 & 26.9 & \\
\hline Career experience year, median $(25 \%, 75 \%)$ & $3(2,5)$ & & $12(10,14)$ & & $20(16,22)$ & & $27.5(18,30)$ & & $<0.001$ \\
\hline Average daily working hour, median $(25 \%, 75 \%)$ & $9(8,10)$ & & $8.75(8,10)$ & & $9(8,10)$ & & $8.9(8,10)$ & & 0.792 \\
\hline Number of nights worked per month, median $(25 \%, 75 \%)$ & $4(3,5)$ & & $3(0,5)$ & & $2.5(0,4)$ & & $2.5(2,4)$ & & $<0.001$ \\
\hline Job strain & & & & & & & & & 0.113 \\
\hline Low strain & 78 & 42.6 & 19 & 28.8 & 25 & 47.2 & 13 & 50.0 & \\
\hline High strain & 105 & 57.4 & 47 & 71.2 & 28 & 52.8 & 13 & 50.0 & \\
\hline Job support & & & & & & & & & 0.099 \\
\hline Low support & 79 & 43.2 & 39 & 59.1 & 28 & 52.8 & 15 & 57.7 & \\
\hline High support & 104 & 56.8 & 27 & 40.9 & 25 & 47.2 & 11 & 42.3 & \\
\hline \multicolumn{10}{|l|}{ Copenhagen burnout inventory, mean $\pm \mathrm{SD}$} \\
\hline Work-related & \multirow{2}{*}{\multicolumn{2}{|c|}{$\begin{array}{l}48.2 \pm 19.74 \\
54.7 \pm 23.54\end{array}$}} & \multicolumn{2}{|c|}{$43.7 \pm 16.20$} & \multicolumn{2}{|c|}{$40.1 \pm 20.11$} & \multicolumn{2}{|c|}{$32.1 \pm 19.05$} & 0.001 \\
\hline Personal & & & & & \multirow{2}{*}{\multicolumn{2}{|c|}{$\begin{array}{l}48.6 \pm 22.09 \\
36.2 \pm 20.44\end{array}$}} & 35.4 & & 0.029 \\
\hline Client-related & \multicolumn{2}{|c|}{$39.9 \pm 22.4$} & \multicolumn{2}{|c|}{$\begin{array}{l}53.7 \pm 16.44 \\
36.3 \pm 16.31\end{array}$} & & & \multicolumn{2}{|c|}{$35.4 \pm 17.37$} & 0.749 \\
\hline Intention to leave & & & & & & & & & 0.014 \\
\hline Yes & 146 & 79.8 & 49 & 74.2 & 33 & 62.3 & 15 & 57.7 & \\
\hline No & 37 & 20.2 & 17 & 25.8 & 20 & 37.7 & 11 & 42.3 & \\
\hline
\end{tabular}

According to age group category, "intention to leave" and all variables were statistically assessed by chi-square tests for categorical variables and one-way analysis of variance for contentious variables. 
Table 2 indicates that women who are in their 20s $(p=0.006)$, who agreed with the concept of gender division of labor $(p=0.003)$, who had longer working hours $(p=0.038)$, who had high levels of strain $(p=0.010)$, and who had higher scores of three domains (all $p>0.001$ ) were more likely to report intentions to leave work. Those with a child $(p=0.005)$ and high levels of support in the workplace $(p<0.001)$ were less likely to report intentions to leave the workplace. Although not reaching significance, nurses who had four or more working nights per month compared with nurses who had three or less working nights tended to have intention to leave $(p=0.097)$.

Table 2. Variables associated with "intention to leave".

\begin{tabular}{|c|c|c|c|c|c|}
\hline \multirow{3}{*}{ Variables } & \multicolumn{5}{|c|}{ Intention to Leave } \\
\hline & \multicolumn{2}{|c|}{ Yes } & \multicolumn{2}{|c|}{ No } & \multirow[t]{2}{*}{$p$} \\
\hline & $N=243$ & $\%$ & $N=85$ & $\%$ & \\
\hline Age group & & & & & 0.006 \\
\hline $20 \mathrm{~s}$ & 146 & 60.1 & 37 & 43.5 & \\
\hline $30 \mathrm{~s}$ & 49 & 20.2 & 17 & 20.0 & \\
\hline 40 s or older & 48 & 19.8 & 31 & 36.5 & \\
\hline Marital status & & & & & 0.906 \\
\hline Married & 76 & 31.3 & 26 & 30.6 & \\
\hline Single (Including Divorced or Widowed) & 167 & 68.7 & 59 & 69.4 & \\
\hline Presence of a child & & & & & 0.005 \\
\hline No & 180 & 74.1 & 49 & 57.7 & \\
\hline Yes & 63 & 25.9 & 36 & 42.4 & \\
\hline Presence of adult family members who needs nursing care & & & & & 0.333 \\
\hline No & 224 & 92.2 & 81 & 95.3 & \\
\hline Yes & 19 & 7.8 & 4 & 4.7 & \\
\hline Hours of weekly domestic chores, median $(25 \%, 75 \%)$ & $2(1,3)$ & & $2(1,3)$ & & 0.560 \\
\hline Hours of weekend domestic chores, median $(25 \%, 75 \%)$ & $3(2,5)$ & & $4(2,5)$ & & 0.581 \\
\hline Work-family conflict & & & & & 0.140 \\
\hline Low & 60 & 24.7 & 28 & 32.9 & \\
\hline High & 183 & 75.3 & 57 & 67.1 & \\
\hline Gender division of labor & & & & & 0.003 \\
\hline Disagree & 89 & 36.6 & 47 & 55.3 & \\
\hline Agree & 154 & 63.4 & 38 & 44.7 & \\
\hline Career experience as present worksite, median $(25 \%, 75 \%)$ & $6(3,13)$ & & $8(3,20)$ & & 0.105 \\
\hline Average daily working hour, median $(25 \%, 75 \%)$ & $9(8,10)$ & & $8(8,10)$ & & 0.038 \\
\hline Number of nights worked per month & & & & & 0.097 \\
\hline Less than 4 & 109 & 44.9 & 47 & 55.3 & \\
\hline 4 or more & 134 & 55.1 & 38 & 44.7 & \\
\hline Job strain & & & & & 0.010 \\
\hline Low strain & 90 & 37.0 & 45 & 52.9 & \\
\hline High strain & 153 & 63.0 & 40 & 47.1 & \\
\hline Job support & & & & & $<0.0001$ \\
\hline Low support & 137 & 56.4 & 24 & 28.2 & \\
\hline High support & 106 & 43.6 & 61 & 71.8 & \\
\hline \multicolumn{6}{|l|}{ Copenhagen burnout inventory, mean \pm SD } \\
\hline Work-related & \multicolumn{2}{|c|}{$49.1 \pm 19.10$} & \multicolumn{2}{|c|}{$32.9 \pm 15.38$} & $<0.0001$ \\
\hline Personal & \multicolumn{2}{|c|}{$56.6 \pm 21.85$} & \multicolumn{2}{|c|}{$40.8 \pm 18.33$} & $<0.0001$ \\
\hline Client-related & \multicolumn{2}{|c|}{$41.9 \pm 20.73$} & \multicolumn{2}{|c|}{$27.5 \pm 16.19$} & $<0.0001$ \\
\hline
\end{tabular}

Table 3 indicates the results of the univariate logistic regression model for the factors associated with intention to leave. Significant factors that increased a risk of intention to leave included being from the younger generation (20s) (OR 2.55, 95\% CI: 1.43-4.54), agreement with the concept of gender division of labor (OR 2.14, 95\% CI: 1.30-3.53), high job strain (OR 1.91, 95\% CI: 1.16-3.15), and a 10-unit increase in three domains of the Copenhagen burnout inventory (OR 1.67, 95\% CI: 1.42-1.97 for WBO, OR 1.42, 95\% CI: 1.25-1.62 for PBO, OR 1.51, 95\% CI: 1.30-1.76 for CBO). Presence of a child (OR 0.48, 
95\% CI: $0.28-0.80$ ) and the presence of high levels of support (OR 0.30, 95\% CI: $0.18-0.52$ ) significantly decreased the risk of intention to leave the workplace.

Table 3. Factors associated with "intention to leave" - univariate logistic regression model.

\begin{tabular}{|c|c|c|c|}
\hline \multirow{3}{*}{ Variables } & \multicolumn{3}{|c|}{ Intention to Leave } \\
\hline & \multirow{2}{*}{ Odds Ratio } & \multicolumn{2}{|c|}{$95 \% \mathrm{CI}$} \\
\hline & & Lower & Upper \\
\hline \multicolumn{4}{|l|}{ Age group } \\
\hline 20 's & 2.55 & 1.43 & 4.54 \\
\hline 30 's & 1.86 & 0.91 & 3.80 \\
\hline 40 's or older & 1.00 & & \\
\hline \multicolumn{4}{|l|}{ Marital status } \\
\hline Married & 1.00 & & \\
\hline Single (including divorced or widowed) & 0.97 & 0.57 & 1.65 \\
\hline \multicolumn{4}{|l|}{ Presence of a child } \\
\hline No & 1.00 & & \\
\hline Yes & 0.48 & 0.28 & 0.80 \\
\hline \multicolumn{4}{|c|}{ Presence of adult family members who needs nursing care } \\
\hline No & 1.00 & & \\
\hline Yes & 1.72 & 0.57 & 5.20 \\
\hline \multicolumn{4}{|l|}{ Weekly domestic labor } \\
\hline More & 0.75 & 0.46 & 1.25 \\
\hline Less & 1.00 & & \\
\hline \multicolumn{4}{|l|}{ Weekend domestic labor } \\
\hline More & 0.85 & 0.51 & 1.40 \\
\hline Less & 1.00 & & \\
\hline \multicolumn{4}{|l|}{ Work-family conflict } \\
\hline Low & 1.00 & & \\
\hline High & 1.50 & 0.88 & 2.57 \\
\hline \multicolumn{4}{|l|}{ Gender division of labor } \\
\hline Disagree & 1.00 & & \\
\hline Agree & 2.14 & 1.30 & 3.53 \\
\hline \multicolumn{4}{|l|}{ Career experience as present worksite } \\
\hline More & 0.86 & 0.52 & 1.44 \\
\hline Less & 1.00 & & \\
\hline \multicolumn{4}{|l|}{ Averaged daily working hours } \\
\hline More & 1.16 & 0.98 & 1.37 \\
\hline Less & 1.00 & & \\
\hline \multicolumn{4}{|l|}{ Number of nights worked per month } \\
\hline Less than 3 & 1.00 & & \\
\hline 4 or more & 1.52 & 0.93 & 2.50 \\
\hline \multicolumn{4}{|l|}{ Job strain } \\
\hline Low strain & 1.00 & & \\
\hline High strain & 1.91 & 1.16 & 3.15 \\
\hline \multicolumn{4}{|l|}{ Job support } \\
\hline Low support & 1.00 & & \\
\hline High support & 0.30 & 0.18 & 0.52 \\
\hline \multicolumn{4}{|l|}{ Copenhagen burnout inventory } \\
\hline Work-related & 1.67 & 1.42 & 1.97 \\
\hline Personal & 1.42 & 1.25 & 1.62 \\
\hline Client-related & 1.51 & 1.30 & 1.76 \\
\hline
\end{tabular}

A logistic regression model was used to investigate influence of each factor on intention to leave. Odds ratio (OR) was computed along with $95 \%$ confidence intervals (95\% CIs). Weekly domestic labor, weekend domestic labor, career experience as the present worksite, and averaged daily working hours were divided by its median. 
Table 4 shows the result of the stepwise multivariable logistic regression model to identify factors associated with intention to leave according to the three domains of the Copenhagen Burnout Inventory. Significant factors identified included age, job support, and the three domains of the Copenhagen Burnout Inventory: younger generation (OR 2.37, 95\% CI: 1.22-4.61 for WBO, OR 2.85, 95\% CI: $1.49-5.46$ for PBO, OR 3.31, 95\% CI: 1.72-6.38 for CBO), high support (OR 0.33, 95\% CI: 0.18-0.60 for WBO, OR 0.28, 95\% CI: 0.16-0.52 for PBO, and OR 0.30, 95\% CI: 0.16-0.55 for CBO), and higher burnout scores (OR 1.58, 95\% CI: 1.32-1.89 for WBO, OR 1.39, 95\% CI: $1.20-1.60$ for PBO, and OR 1.47, 95\% CI: 1.24-1.73 for CBO). The interaction among age, JCQ support, and the three domains did not reach statistical significance.

Table 4. Stepwise multivariable regression model for factors associated with "intention to leave" adjusting for each domain of the Copenhagen Burnout Inventory.

\begin{tabular}{|c|c|c|c|c|c|c|c|c|c|}
\hline \multirow{3}{*}{ Variable } & \multicolumn{3}{|c|}{ Work-Related Burnout } & \multicolumn{3}{|c|}{ Personal Burnout } & \multicolumn{3}{|c|}{ Client-Related Burnout } \\
\hline & \multirow{2}{*}{$\begin{array}{l}\text { Odds } \\
\text { Ratio }\end{array}$} & \multicolumn{2}{|c|}{$95 \%$ CI } & \multirow{2}{*}{$\begin{array}{l}\text { Odds } \\
\text { Ratio }\end{array}$} & \multicolumn{2}{|c|}{$95 \% \mathrm{CI}$} & \multirow{2}{*}{$\begin{array}{l}\text { Odds } \\
\text { Ratio }\end{array}$} & \multicolumn{2}{|c|}{$95 \% \mathrm{CI}$} \\
\hline & & Lower & Upper & & Lower & Upper & & Lower & Upper \\
\hline \multicolumn{10}{|l|}{ Age } \\
\hline $20 \mathrm{~s}$ & 2.37 & 1.22 & 4.61 & 2.85 & 1.49 & 5.46 & 3.31 & 1.72 & 6.38 \\
\hline $30 \mathrm{~s}$ & 1.52 & 0.69 & 3.35 & 1.49 & 0.69 & 3.24 & 1.90 & 0.86 & 4.16 \\
\hline 40 s or older & 1.00 & & & 1.00 & & & 1.00 & & \\
\hline \multicolumn{10}{|l|}{ Job strain } \\
\hline Low strain & 1.00 & & & 1.00 & & & 1.00 & & \\
\hline High strain & 0.92 & 0.51 & 1.67 & 0.88 & 0.48 & 1.61 & 1.02 & 0.57 & 1.82 \\
\hline \multicolumn{10}{|l|}{ Job support } \\
\hline Low support & 1.00 & & & 1.00 & & & 1.00 & & \\
\hline High support & 0.33 & 0.18 & 0.60 & 0.28 & 0.16 & 0.52 & 0.30 & 0.16 & 0.55 \\
\hline \multicolumn{10}{|c|}{ Copenhagen burnout inventory } \\
\hline Work-related & 1.58 & 1.32 & 1.89 & & & & & & \\
\hline Personal & & & & 1.39 & 1.20 & 1.60 & & & \\
\hline Client-related & & & & & & & 1.47 & 1.24 & 1.73 \\
\hline
\end{tabular}

\section{Discussion}

In this study of Japanese female nurses working for three university affiliated hospitals, we investigated factors associated with intention to leave the workplace. Of particular relevance was perceptions toward the gender division of labor. After adjusting for the working and personal life conditions of individuals, we identified that women in their 20s and those who had higher burnout scores had an increased risk of intention to leave, supporting the international literature on the high turnover of newly qualified nurses [6,7,34], whereas job support provided protection and decreased this risk. We found that perceptions on the gender division of labor and work-family conflict were not associated with intention to leave a workplace among female nurses in this university setting.

In this study, agreeing with the gender division of labor did not influence intention to leave. According to the Cabinet Survey of Japan [19], more than half of women agreed that the mother should stay home when a child is young. This idea is widely accepted by older Japanese people, believing that children need their mothers to be disciplined well. Women are more likely to apply for parental leave, but very few men do [35]. Women who agree with gender division of labor have long been thought to tend to quit working following life events such as marriage, pregnancy, or child rearing. However, this present study demonstrated that upholding views about the importance of gender division of labor are not in conflict with continuous employment and career development and do not increase the risk of intention to leave the workplace among nurses. Alternatively, as the majority of the respondents in our study sample were not married, our subjects may not yet have family responsibilities. If the majority of our subjects had children and family responsibilities, their agreement with gender division 
in labor might have had a different effect on intention to leave a workplace from that observed in the present study, but the direction of this potential bias may not be clear and may or may not result in random error.

The literature suggests that work-family conflict may be a real obstacle for women to continuously work $[24,36,37]$.

The discrepancy between the non-significant result for work-family conflict in our study and previous studies could be explained by Yamaguchi et al. recruiting older nurses. This suggests that being older may increase the perception of increased work-family conflict. The majority of our study population was not married, indicating that they were less likely to experience work-family conflict, although $78 \%$ of our subjects perceived that they had work-family conflict. According to the labor force survey of the Japanese government, the age-stratified labor participation rate declines in the late 20 s, and again in the early in their 40s, when women bear and raise children. This hiatus is called an M-curve, suggesting that women in these two age bands face work-family conflicts [38]. Our sample population may be younger than these age generations, suggesting high percentages of self-reported work-family conflict may reflect a psychological response to an as-yet unrealized fear of the future. Literature in this area of research reported that it is generally challenging for novice nurses to have an accurate perspective of their profession and to obtain job satisfaction [39] and thus it is important to support them during the process of acquiring specialized skills in nursing [40]. Although we cannot be sure if the reported high percentage of work-family conflict does reflect a psychological response to unconscious fear toward the future profession, we should explore this further together with the significance of being younger in age and the increased risk of intention to leave.

This study demonstrated that young female nurses are more likely to leave the workplace, supporting the international literature highlighting a high turnover of newly qualified nurses $[6,7,34]$. We also identified that the average daily working hours were the longest and number of nights worked per month was highest for nurses in their 20s. These two working conditions were not selected in the final logistic model but univariate analyses identified that these two conditions significantly increased the risk of intention to leave the workplace. Our additional analyses demonstrated that working hours and the number of on-calls became nonsignificant when adjusting for age. Thus, working conditions on their own were not associated with intention to leave, but age was a strong determinant. This indicates that young nurses, like student nurses, are less resilient to stress than experienced nurses. Previously, a Japanese study on nurses reported that individual nurse burnout, dissatisfaction, and poorer quality of care were associated with workplaces that have a larger percentages of inexperienced nurses [41]. Studies on student nurses showed they are more affected than older nurses by workplace violence experiences, report more distress [42], and that distressed student nurses learn less than their colleagues [43]. The state of distress, in turn, exposes nurses to workplace violence [44,45]. Psychosocial factors and violence are important factors for withdrawal, and future studies should be undertaken in this direction. Thus, for inexperienced young nurses, their retention at work could be improved if they had more support from seniors, were trained further on practical skills and on how to adapt themselves to work efficiently, and if long working hours are avoided.

We demonstrated that social support from seniors or colleagues did have a protective role for those who reported an intention to leave the workplace. The hierarchy amongst nurses is supported and nurses are ranked by their level of education and licensure, as well as years of experience. Therefore, inexperienced young nurses may tend to be left alone at work. In addition to having preceptors present in the nurse education system, a mentor and an experienced and trusted external adviser could be used as social support for young female nurses to avoid their leaving the workplace so soon after qualification. Our previous study identified that a consultation service offered by an external body, such as the section for diversity, was effective in reducing burnout among medical faculties [46]. Two earlier studies about nurses in Japan reported that nurses who experience high levels of job control or work engagement (protective indicators) tend to be retained [24,25]. However, nurses in these two studies were much older than those in our sample, which may account for the insignificant findings 
of job control in our study. In addition, two previous nurse studies had different research questions from ours, focusing more on experienced nurses: one study focused on characteristics of workplace including hospital, home health care and nursing home, and the other study investigated long-term care nurses.

A strength of this study was that we were able to investigate both individual factors of work and private life. Furthermore, this study enabled us to evaluate how the perceptions of gender division of labor affect decision-making about continuing employment among female nurses. Finally, despite the small sample size, the majority of our subjects were young, single, and new graduates from nursing schools, and therefore we were able to investigate factors associated with intention to leave particularly among the young female nurse profession. There are several limitations to address in addition to the small sample size. First, this study used a self-reported survey; therefore, it is possible that those who did not participate may or may not face a high degree of burnout. Second, our target population of nurses did not include male nurses. Recently, the number of male nurses is increasing and we do not know if they experience more psychological stress working in a woman-dominated job. Future studies on nurse retention should therefore include male nurses. Third, we did not collect information about life events that cause psychological stress. Burnout measured in this study may be influenced by such psychological events. Fourth, we did not measure organizational factors. Previously, we suggested that organizational climate with gender equity mitigates burnout among university academics [46]. Despite these limitations, we demonstrated that those who were young and perceived burnout were more likely to leave the workplace, but the presence of social support reduced the risk of the intention to leave the workplace. In addition, we confirmed that the perception of the gender division of labor was not associated with intention to leave the workplace, suggesting that agreement with the gender division of labor did not harm the decision to continue work.

\section{Conclusions}

This study found that perceptions toward the gender division of labor were not associated with intention to leave the workplace, or rather the young generation (in their 20s) are the most vulnerable population to quitting working. The idea of the gender division of labor is respected in the Japanese mindset as "Good Wives and Wise Mothers". The result of this study suggests that the gender division of labor does not conflict with work continuation. From the perspective of Human Resource Management, the retention of newly certified nurses is key to running medical institutions. This study confirmed that nurses who experience burnout were more likely to intend to leave work, which is consistent with previous studies. Social support from senior and colleague including preceptorship, mentorship, and consultation services at the work place would be beneficial for young female nurses.

Author Contributions: K.N. initiated the idea and designed the study; H.O., A.T., and H.H. collected the data; Y.I. and S.M. analyzed the data and wrote the paper. K.N. edited the draft and reanalyzed data and had primary responsibility for the final content. J.I. critically reviewed the draft and provided important intellectual content to the interpretation of the results. All the authors read and approved the final manuscript.

Funding: This study was supported by the Ministry of Education, Culture, Sports, Science and Technology, Japan (Grants for Scientific Research [B], Number 16H0526).

Acknowledgments: We thank Miss Ayako Inoue, Miss Haruko Sekiya, and Mrs. Yoko Nakayama for their help with data collection.

Conflicts of Interest: The authors declare that no conflict of interest exist.

\section{References}

1. Buchan, J. Reviewing the benefits of health workforce stability. Hum. Resour. Health 2010, 8, 29. [CrossRef] [PubMed]

2. Beecroft, P.C.; Kunzman, L.; Krozek, C. RN internship: Outcomes of a one-year pilot program. J. Nurs. Adm. 2001, 31, 575-582. [CrossRef] [PubMed] 
3. Duffield, C.M.; Roche, M.A.; Homer, C.; Buchan, J.; Dimitrelis, S. A comparative review of nurse turnover rates and costs across countries. J. Adv. Nurs. 2014, 70, 2703-2712. [CrossRef] [PubMed]

4. Rush, K.L.; Adamack, M.; Gordon, J.; Lilly, M.; Janke, R. Best practices of formal new graduate nurse transition programs: An integrative review. Int. J. Nurs. Stud. 2013, 50, 345-356. [CrossRef] [PubMed]

5. Flinkman, M.; Isopahkala-Bouret, U.; Salanterä, S. Young Registered Nurses' Intention to Leave the Profession and Professional Turnover in Early Career: A Qualitative Case Study. ISRN Nurs. 2013, 2013, 916061. [CrossRef]

6. Rudman, A.; Gustavsson, P.; Hultell, D. A prospective study of nurses' intentions to leave the profession during their first five years of practice in Sweden. Int. J. Nurs. Stud. 2014, 51, 612-624. [CrossRef] [PubMed]

7. Aiken, L.H.; Clarke, S.P.; Sloane, D.M.; Sochalski, J.; Silber, J.H. Hospital Nurse Staffing and Patient Mortality, Nurse Burnout, and Job Dissatisfaction. JAMA 2002, 288, 1987-1993. [CrossRef]

8. Rafferty, A.M.; Clarke, S.P.; Coles, J.; Ball, J.; James, P.; McKee, M.; Aiken, L.H. Outcomes of variation in hospital nurse staffing in English hospitals: Cross-sectional analysis of survey data and discharge records. Int. J. Nurs. Stud. 2007, 44, 175-182. [CrossRef]

9. Chachula, K.M.; Myrick, F.; Yonge, O. Letting go: How newly graduated registered nurses in Western Canada decide to exit the nursing profession. Nurse Educ. Today 2015, 35, 912-918. [CrossRef]

10. Kramer, M. Reality Shock: Why Nurses Leave Nursing; LWW: Philadelphia, PA, USA, 1975; Volume 75.

11. Martin, K.; Martin, K.; Martin, K. Newly Registered Nurses' Experience in the First Year of Practice: A Phenomenological Study. Int. J. Hum. Caring 2011, 15, 21-27. [CrossRef]

12. Rudman, A.; Gustavsson, J.P. Early-career burnout among new graduate nurses: A prospective observational study of intra-individual change trajectories. Int. J. Nurs. Stud. 2011, 48, 292-306. [CrossRef] [PubMed]

13. Giallonardo, L.M.; Wong, C.A.; Iwasiw, C.L. Authentic leadership of preceptors: Predictor of new graduate nurses' work engagement and job satisfaction. J. Nurs. Manag. 2010, 18, 993-1003. [CrossRef]

14. Cooper Brathwaite, A.; Lemonde, M. Team Preceptorship Model: A Solution for Students' Clinical Experience. ISRN Nurs. 2011, 530357. [CrossRef] [PubMed]

15. Sedgwick, M.; Harris, S. A Critique of the Undergraduate Nursing Preceptorship Model. Nurs. Res. Pract. 2012, 248356. [CrossRef]

16. Yamazaki, T.; Ishida, M.; Kashiwagura, E. The relation between a tendency of burnout and social support among nurses: A comparative study of constituent members in two different hospitals. Bull. Coll. Med. Sci. Tohoku Univ. 1999, 8, 161-170.

17. Bilge, F. Examining the burnout of academics in relation to job satisfaction and other factors. Soc. Behav. Pers. Int. J. 2006, 34, 1151-1160. [CrossRef]

18. Ministry of Health, Labor and Welfare. Kango Shokuin Shūgyō Jōkyō-tō Jittai Chōsa. 2011. Available online: https://www.mhlw.go.jp/stf/houdou/2r98520000017cjh.html (accessed on 10 December 2018). (In Japanese)

19. Cabinet Office, Government of Japan. Jyosei no Katsuyaku Suishin ni Kansuru Yorontyosa. 2014. Available online: https://survey.gov-online.go.jp/h26/h26-joseikatsuyaku/index.html (accessed on 10 December 2018).

20. Nomura, K.; Yamazaki, Y.; Gruppen, L.D.; Horie, S.; Takeuchi, M.; Illing, J. The difficulty of professional continuation among female doctors in Japan: A qualitative study of alumnae of 13 medical schools in Japan. BMJ Open 2015, 5, e005845. [CrossRef]

21. The Global Gender Gap Report 2017. World Economic Forum. Available online: http://www3.weforum.org/ docs/WEF_GGGR_2017.pdf (accessed on 10 December 2018).

22. Flinkman, M.; Leino-Kilpi, H.; Salantera, S. Nurses' Intention to Leave the Profession: Integrative Review. J. Adv. Nurs. 2010, 66, 1422-1434. [CrossRef]

23. Tei-Tominaga, M. Factors related to the intention to leave and the decision to resign among newly graduated nurses: A complete survey in a selected prefecture in Japan. Environ. Health Prev. Med. 2013, 18, $293-305$. [CrossRef]

24. Yamaguchi, Y.; Inoue, T.; Harada, H.; Oike, M. Job control, work-family balance and nurses' intention to leave their profession and organization: A comparative cross-sectional survey. Int. J. Nurs. Stud. 2016, 64, 52-62. [CrossRef]

25. Eltaybani, S.; Noguchi-Watanabe, M.; Igarashi, A.; Saito, Y.; Yamamoto-Mitani, N. Factors related to intention to stay in the current workplace among long-term care nurses: A nationwide survey. Int. J. Nurs. Stud. 2018, 80, 118-127. [CrossRef] [PubMed] 
26. Mor Barak, M.E.; Nissly, J.A.; Levin, A. Antecedents to Retention and Turnover among Child Welfare, Social Work, and Other Human Service Employees: What Can We Learn from Past Research? A Review and Metanalysis. Soc. Serv. Rev. 2001, 75, 625-661. [CrossRef]

27. Mobley, W.H. Employee Turnover: Causes, Consequences, and Control; Addison-Wesley: Boston, MA, USA, 1982; pp. 1-205.

28. Tei, M.; Yamazaki, Y. The impact of work and organizational characteristics on the health status, job dissatisfaction and turnover intentions of workers in an information service industry. Sangyo Eiseigaku Zasshi 2003, 45, 20-30. [CrossRef] [PubMed]

29. Watai, I.; Nishikido, N.; Murashima, S. Development of a Japanese Version of the Work-Family Conflict Scale (WFCS), and examination of its validity and reliability. Sangyo Eiseigaku Zasshi 2006, 48, 71-81. [CrossRef]

30. Kristensen, T.S.; Borritz, M.; Villadsen, E.; Christensen, K.B. The Copenhagen Burnout Inventory: A new tool for the assessment of burnout. Work Stress 2005, 19, 192-207. [CrossRef]

31. Karasek, R.A., Jr. Job demands, job decision latitude, and mental strain: Implications for job redesign. Adm. Sci. Q. 1979, 285-308. [CrossRef]

32. Karasek, R.; Brisson, C.; Kawakami, N.; Houtman, I.; Bongers, P.; Amick, B. The Job Content Questionnaire (JCQ): An instrument for internationally comparative assessments of psychosocial job characteristics. J. Occup. Health Psychol. 1998, 3, 322-355. [CrossRef]

33. Kawakami, N.; Kobayashi, F.; Araki, S.; Haratani, T.; Furui, H. Assessment of job stress dimensions based on the job demands-control model of employees of telecommunication and electric power companies in Japan: Reliability and validity of the Japanese version of the Job Content Questionnaire. Int. J. Behav. Med. 1995, 2, 358-375. [CrossRef]

34. Kovner, C.T.; Brewer, C.S.; Fatehi, F.; Jun, J. What does nurse turnover rate mean and what is the rate? Policy Politics Nurs. Pract. 2014, 15, 64-71. [CrossRef]

35. Ministry of Health, Labor and Welfare. Basic Survey of Gender Equality in Employment Management. 2017. Available online: https://www.mhlw.go.jp/toukei/list/71-29r.html (accessed on 13 December 2018).

36. Brewer, C.S.; Kovner, C.T.; Greene, W.; Cheng, Y. Predictors of RNs' intent to work and work decisions 1 year later in a U.S. national sample. Int. J. Nurs. Stud. 2009, 46, 940-956. [CrossRef]

37. Nei, D.; Snyder, L.; Litwiller, B. Promoting retention of nurses. Health Care Manag. Rev. 2015, 40, $237-253$. [CrossRef] [PubMed]

38. Ministry of Internal Affairs and Communications. Statistics Bureau of Japan "Labor Force Survey". 2016. Available online: https://www.stat.go.jp/english/data/roudou/index.html (accessed on 13 December 2018).

39. Whitehead, J. Newly qualified staff nurses' perceptions of the role transition. Br. J. Nurs. 2001, 10, 330-339. [CrossRef] [PubMed]

40. Messmer, P.R.; Jones, S.G.; Taylor, B.A. Enhancing knowledge and self-confidence of novice nurses: The "Shadow-A-Nurse" ICU program. Nurs. Educ. Perspect. 2004, 25, 131-136. [PubMed]

41. Kanai-Pak, M.; Aiken, L.H.; Sloane, D.M.; Poghosyan, L. Poor work environments and nurse inexperience are associated with burnout, job dissatisfaction and quality deficits in Japanese hospitals. J. Clin. Nurs. 2008, 17, 3324-3329. [CrossRef] [PubMed]

42. Magnavita, N.; Heponiemi, T. Workplace violence against nursing students and nurses: An Italian experience. J. Nurs. Scholarsh. 2011, 43, 203-210. [CrossRef] [PubMed]

43. Magnavita, N.; Chiorri, C. Academic stress and active learning of nursing students: A cross-sectional study. Nurse Educ. Today 2018, 68, 128-133. [CrossRef] [PubMed]

44. Magnavita, N. The exploding spark: Workplace violence in an infectious disease hospital—A longitudinal study. BioMed Res. Int. 2013, 2013, 316358. [CrossRef]

45. Magnavita, N. Workplace violence and occupational stress in healthcare workers: A chicken-and-egg situation-results of a 6-year follow-up study. J. Nurs. Scholarsh. 2014, 46, 366-376. [CrossRef]

46. Taka, F.; Nomura, K.; Horie, S.; Takemoto, K.; Takeuchi, M.; Takenoshita, S.; Murakami, A.; Hiraike, H.; Okinaga, H.; Smith, D.R. Organizational climate with gender equity and burnout among university academics in Japan. Ind. Health 2016, 54, 480-487. [CrossRef]

(C) 2019 by the authors. Licensee MDPI, Basel, Switzerland. This article is an open access article distributed under the terms and conditions of the Creative Commons Attribution (CC BY) license (http://creativecommons.org/licenses/by/4.0/). 